\title{
Possible source of ancient carbon in phytolith concentrates from harvested grasses
}

\author{
G. M. Santos ${ }^{1}$, A. Alexandre ${ }^{2}$, J. R. Southon ${ }^{1}$, K. K. Treseder ${ }^{3}$, R. Corbineau ${ }^{2}$, and P. E. Reyerson ${ }^{4}$ \\ ${ }^{1}$ Earth System Science, University of California, Irvine, B321 Croul Hall, Irvine CA 92697-3100, USA \\ ${ }^{2}$ CEREGE, CNRS, UPCAM-III, Europôle méditerranéen de l'Arbois BP 80, 13545, Aix en Provence cedex 04, France \\ ${ }^{3}$ Department of Ecology and Evolutionary Biology, University of California, Irvine CA 92697, USA \\ ${ }^{4}$ Department of Geography, University of Wisconsin-Madison, 550 North Park Street, Madison WI 53706, USA
}

Correspondence to: G. M. Santos (gdossant@uci.edu)

Received: 6 September 2011 - Published in Biogeosciences Discuss.: 11 January 2012

Revised: 19 April 2012 - Accepted: 30 April 2012 - Published: 29 May 2012

\begin{abstract}
Plants absorb and transport silicon (Si) from soil, and precipitation of $\mathrm{Si}$ within the living plants results in micrometric amorphous biosilica particles known as phytoliths. During phytolith formation, a small amount of carbon $(<2 \%)$ can become occluded in the silica structure (phytC) and therefore protected from degradation by the environment after plant tissue decomposition. Since the major $\mathrm{C}$ source within plants is from atmospheric carbon dioxide $\left(\mathrm{CO}_{2}\right)$ via photosynthesis, the current understanding is that the radiocarbon $\left({ }^{14} \mathrm{C}\right)$ content of phytC should reflect the ${ }^{14} \mathrm{C}$ content of atmospheric $\mathrm{CO}_{2}$ at the time the plant is growing. This assumption was recently challenged by ${ }^{14} \mathrm{C}$ data from phytoliths extracted from living grasses that yielded ages of several thousand years (2-8 kyr BP; in radiocarbon years "Before Present" (BP), "Present" being defined as 1950). Because plants can take up small amounts of $\mathrm{C}$ of varying ages from soils (e.g., during nutrient acquisition), we hypothesized that this transported $\mathrm{C}$ within the plant tissue could be attached to or even embedded in phytoliths. In this work, we explore this hypothesis by reviewing previously published data on biosilica mineralization and plant nutrient acquisition as well as by evaluating the efficiency of phytolith extraction protocols from scanning electron microscope (SEM) images and energy dispersive spectrometer (EDS) analyses from harvested grasses phytolith concentrates. We show that current extraction protocols are inefficient since they do not entirely remove recalcitrant forms of $\mathrm{C}$ from plant tissue. Consequently, material previously measured as "phytC" may contain at least some fraction of soil-derived C (likely radiocarbon-old) taken up by roots. We also suggest a novel
\end{abstract}

interpretation for at least some of the phytC - which enters via the root pathway during nutrient acquisition - that may help to explain the old ages previously obtained from phytolith concentrates.

\section{Introduction}

Phytoliths are amorphous silica particles that precipitate in and/or between the cells of living plants. The occurrence of silicon ( $\mathrm{Si}$ ) within the plant is a result of its uptake from soils and its precipitation at a final location (Currie and Perry, 2007; Epstein, 2009). Phytoliths range from 1 to several tens of $\mu \mathrm{m}$ in diameter and can take the morphology of the cells from which they originate. Incorporation of $\mathrm{Si}$ into plants has been well documented (Prychid et al., 2003); however, the means by which plants are able to transport $\mathrm{Si}$ and control its polymerization are still not fully understood (Bauer et al., 2011). Phytoliths can contain small amounts of other elements, including $\mathrm{C}$ (phytC, assumed to range from 0.1 to $2 \%$ of phytolith dry weight) occluded in their structure (Prychid et al., 2003; Santos et al., 2010a; Wilding, 1967). It is generally assumed that the source of this phytC is atmospheric $\mathrm{CO}_{2}$ that was fixed by the plant via photosynthesis (Carter, 2009; Kelly et al., 1991; Piperno, 2006; Raven et al., 1999; Wilding, 1967).

Because phytoliths are normally well preserved in oxidizing environments, their morphological assemblages have been widely used for paleo-environmental reconstructions and archaeological and paleontological research (e.g., 
Piperno and Becker, 1996; Alexandre et al., 1999; Prebble et al., 2002; Prasad et al., 2005; Bremond et al., 2005, 2008a, b; Piperno, 2006; Alam et al., 2009; Neumann et al., 2009; Rossouw et al., 2009). In parallel, quantification of phytoliths in plants, soils, and rivers has been used to study the biogeochemical cycle of silica, which itself is coupled to the global C cycle (Blecker et al., 2006; Struyf et al., 2009; Cornelis et al., 2011; Alexandre et al., 2011). Carbon isotopic studies have investigated the potential of phytC $\delta^{13} \mathrm{C}$ signatures for providing information about photosynthetic pathways (Kelly et al., 1991; Smith and White, 2004; Stromberg and McInerney, 2011) or deriving a paleo-atmospheric $\mathrm{CO}_{2}$ record (Carter, 2009). Researchers have been also speculating that promoting the growth of cultivars capable of producing large concentrations of phytoliths might enhance $\mathrm{C}$ sequestration through slow build-up of phytolith-protected organic matter (OM) in soils (Sullivan and Parr, 2007; Jansson et al., 2011). To validate most of the phytC studies mentioned above, there is a need to demonstrate that (1) the $\mathrm{C}$ analyzed is not contaminated by plant tissue residues, soils or sediments, and (2) "modern" phytC is an accurate indicator of present-day atmospheric $\mathrm{CO}_{2}$ conditions.

In a recent collaboration between the University of California, Irvine (UCI, USA), CEREGE (France), and the University of Wisconsin-Madison (UW, USA), the following issues, related to the direct ${ }^{14} \mathrm{C}$ dating by accelerator mass spectrometry (AMS), were addressed for the first time: (a) the background assessment of the chemical phytolith extraction procedure, and (b) replication of ${ }^{14} \mathrm{C}$-AMS measurements on aliquots from large pools of chemically extracted phytolith concentrates (Santos et al., 2010a). This study produced two sets of highly surprising results. The apparent ${ }^{14} \mathrm{C}$ age of phytolith concentrates from a top-colluvial soil (Kandara) got older by more than $1.5 \mathrm{kayr}$ (Table 1 ) when repurified to remove potential contamination from non-phytC organic residues recalcitrant to a first chemical extraction (Fig. 1). In addition, ${ }^{14} \mathrm{C}$ results from phytolith concentrates extracted from harvested living grasses (samples IDs are Grass 1, MN and Biocore) were inexplicably old by several thousand years, though bulk material from the same plant gave contemporary ${ }^{14} \mathrm{C}$ values (Table 2). The laboratories and chemicals involved in the phytolith extraction and AMS sample preparation were thoroughly checked for sources of exogenous $\mathrm{C}$ contaminants, and none were found.

Contrary to previous efforts to directly date phytC, this work included a very comprehensive blank assessment for the phytolith extraction procedure, involving a suite of ${ }^{14} \mathrm{C}$ measurements on modern and ${ }^{14} \mathrm{C}$-free materials that can mimic phytolith structure, which showed that exogenous $\mathrm{C}$ associated with the chemical extraction was $\sim 3 \mu \mathrm{g}$ of modern and $\sim 2 \mu \mathrm{g}$ of dead $\left({ }^{14} \mathrm{C}\right.$-free $)$ carbon $(n=10)$. Therefore, the results shown in Tables 1 and 2 were already corrected for any source of modern and dead C added by the phytolith extraction procedure and subsequent AMS sample processing. Moreover, the shift towards old ${ }^{14} \mathrm{C}$ results was too large to be resolved by any blank issues, unless most of the $\mathrm{C}$ measured was from "natural" exogenous $\mathrm{C}$ acquired in the field, which was not accounted for in lab blanks. Details of the phytolith extractions, blank assessment and the examination of $\mathrm{C}$ sources contaminants have been addressed elsewhere (Santos et al., 2010a).

These intriguing ${ }^{14} \mathrm{C}$ results raised the following questions: (a) can a chemical extraction procedure that does not use solvents or plastic devices (possible sources of older exogenous C) affect the final ${ }^{14} \mathrm{C}$ results?; (b) can root uptake be a source of old $\mathrm{C}$ that may be recalcitrant to the extraction procedures, and therefore remain on the phytolith concentrates?; and (c) what are the sources of phytC itself: carbon fixed solely via photosynthesis, or taken up by roots, or both? In this overview paper, we will attempt to answer these questions by reviewing the literature on the silicification process and its functions, as well as nutrient acquisition and inorganic $\mathrm{C}$ incorporation by roots versus photosynthesis. We will also address the common assumptions of the source of $\mathrm{C}$ within phytoliths, its $\delta^{13} \mathrm{C}$ signature, and ${ }^{14} \mathrm{C}$ dating results. Moreover, we will discuss how current phytolith chemical extraction procedures for isotopic analyses of $\mathrm{C}$ may be inadequate, because they appear to leave organic compound residues in phytolith concentrates.

\section{The silicification process and its roles}

Phytolith production is carried out in an aqueous environment in the plant from undersaturated solutions of silicic acid $\left(\mathrm{H}_{4} \mathrm{SiO}_{4}\right)$, at atmospheric pressure. In terms of concentrations, plants can be classified as high, intermediate, and non-Si accumulators. High accumulators typically exhibit $\mathrm{SiO}_{2}$ concentrations $>1 \%$ dry weight, and active dissolved $\mathrm{Si}$ (DSi) uptake (higher than the mass flow-driven flux) when soil DSi concentrations are low (Henriet et al., 2006). Such an active DSi uptake may be genetically controlled, as in rice (Ma et al., 2006). The intermediate group accumulates $\sim 1 \% \mathrm{SiO}_{2}$ dry weight, whereas non-accumulators exclude it (Marschner, 1995; Epstein, 1999; Raven et al., 1999; Hodson et al., 2005; Ma and Yamaji, 2006; Street-Perrott and Barker, 2008). Bio-macromolecule fragments (acidic aminoacids, glycoproteins and lipids) isolated from phytoliths indicate that the silicic acid polymerization is rapid and energetic, and might encapsulate those same molecules that are thought to be responsible for the Si nucleation process (Bauer et al., 2011). Furthermore, the Si transport process appears to be genetically controlled, as Si-transporter genes have been identified for rice (Ma et al., 2004, 2006, 2007a, b; Mitani et al., 2009; Tamai and Ma, 2008), and a genetic basis for the presence of $\mathrm{SiO}_{2}$ in wheat awns has been suggested (Peleg et al., 2010).

Assumed beneficial effects of biogenic Si include that it (a) acts as stiffening material, promoting root oxygen supply, upright stature, resistance to lodging (falling over) and helps 


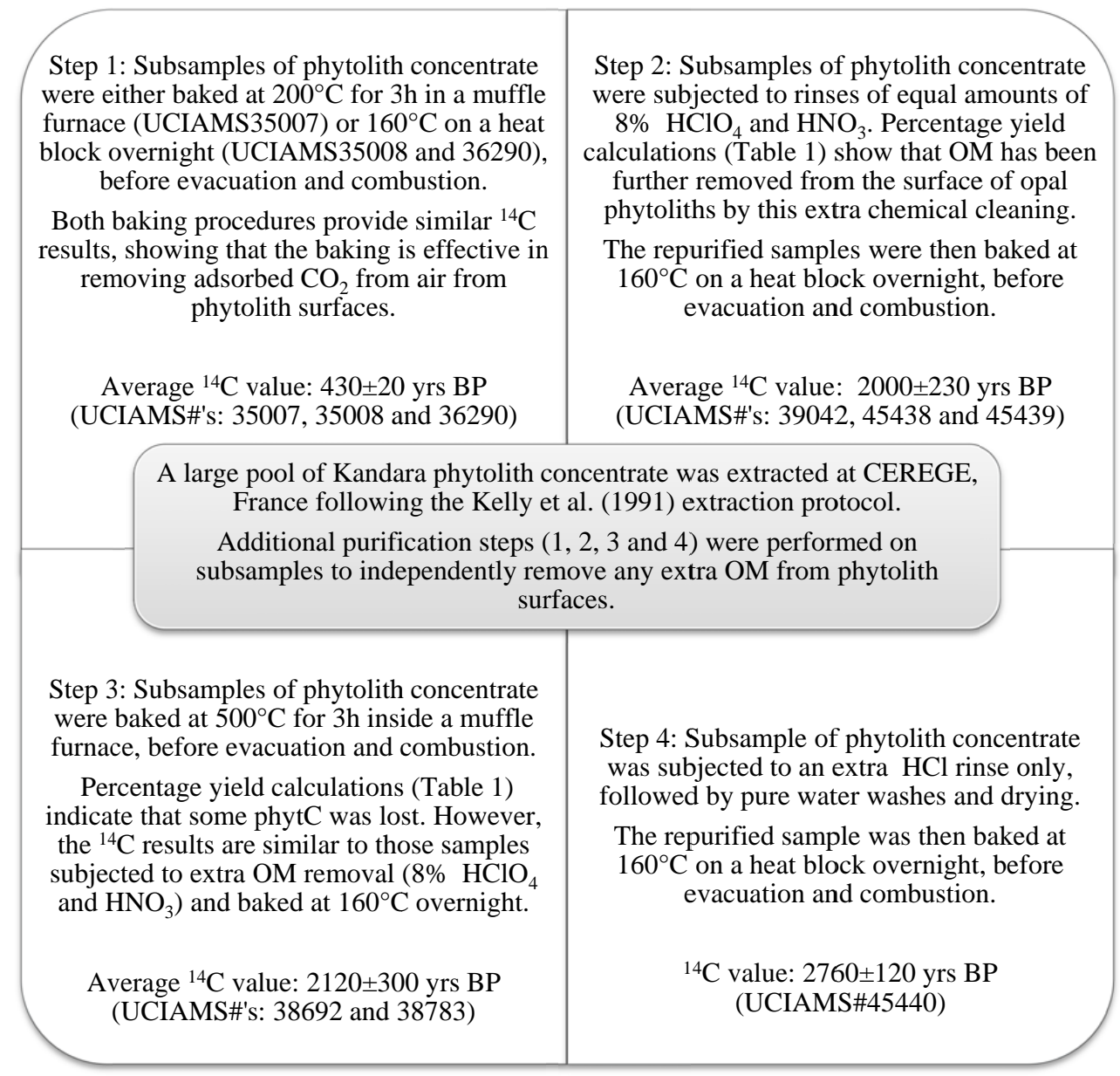

Fig. 1. Additional purification steps processed on the Kandara phytolith concentrate. Average of ${ }^{14} \mathrm{C}$ ages from repurified material is indicated.

leaves to expose themselves to light; (b) enhances growth and yield; (c) reduces vulnerability to pathogens (Ranganathan et al., 2006; Naidoo et al., 2009); (d) makes plants more distasteful to grazing insects, molluscs, and mammals; (e) reduces nutrient imbalance (e.g., nitrogen excess and phosphorus deficiency) and prevents metal toxicity by sequestering aluminum, iron, manganese, cadmium and zinc; and (f) helps protect against temperature extremes, as well as reducing transpiration (diminishing the impact of drought and salinity stress) (Ma et al., 2001; Hodson et al., 2005; Ma and Yamaji, 2006; Street-Perrott and Barker, 2008; Epstein, 2009; Cornelis et al., 2011).

\section{Isotope analyses of phytC}

By the late 1960s, researchers were aware that the silicification process results in the occlusion of $\mathrm{C}$ within phytoliths, since a portion of the total organic $\mathrm{C}$ measured was not susceptible to oxidation. Wilding (1967) considered that phytC was most likely the original cytoplasmic organic constituent within the plant cell, around which in vivo silicification had taken place. Because the enclosure provides protection for the C, Wilding (1967) suggested that this C should be suitable for ${ }^{14} \mathrm{C}$ dating. Seventy-five grams of biogenetic opal were extracted from $45 \mathrm{~kg}$ of soil. Sixty grams of this material were dated by ${ }^{14} \mathrm{C}$ decay counting and yielded $13.3 \mathrm{kyr} \mathrm{BP}$, when the expected age was $1-1.5 \mathrm{kyr}$ BP (based on the sample size and accumulation rates of grass vegetation). Wilding (1967) speculated that preferential oxidation of younger opal structures versus older ones might explain the anomalous age and suggested not using direct dating of phytC to reconstruct vegetation until the problem was better understood. Due to the low concentrations of phytoliths in plants and the very large sample sizes required, further direct ${ }^{14} \mathrm{C}$ dating of phytC was not pursued for many years.

Direct counting of ${ }^{14} \mathrm{C}$ atoms with accelerator mass spectrometry (AMS) allowed far smaller samples to be handled and measured (Santos et al., 2007, 2010b), but despite the obvious advantages of AMS, only a few attempts to directly date phytoliths have been carried out (Kelly et al., 1991; 
Table 1. Radiocarbon results shown are from several aliquots of a large soil phytolith concentrate (Kandara, described in Santos et al., 2010a). The PhytC was originally assumed to have a "modern" signal (decades or a few hundred years old), as the phytolith assemblage reflects the current vegetation (Bremond et al., 2005). After the first chemical phytolith extraction was performed, following the Kelly et al. (1991) phytolith extraction protocol for soils, subsamples from this phytolith pool were repurified (Santos et al., 2010a) either by baking and/or by extra wet oxidation steps, as illustrated in Fig. 1. Radiocarbon concentrations are given as fraction modern $\mathrm{C}$ and conventional ${ }^{14} \mathrm{C}$ age (yr BP). Mass balance blank subtractions have been applied to samples using the quantified blank data and formulae presented in Santos et al. (2007). Table adapted from Santos et al. (2010a).

\begin{tabular}{|c|c|c|c|c|c|c|c|c|c|c|}
\hline $\begin{array}{l}\text { Extra } \\
\text { extraction } \\
\text { steps }\end{array}$ & UCIAMS\# & $\begin{array}{l}\text { Sample } \\
(\mathrm{mg})\end{array}$ & $\begin{array}{l}\text { Graphite } \\
(\mathrm{mgC})\end{array}$ & $\begin{array}{l}\text { Sample } \\
\text { yield (\%) }\end{array}$ & $\begin{array}{l}\text { Fraction } \\
\text { Modern }\end{array}$ & $\pm 1 \sigma$ & $\begin{array}{l}{ }^{14} \mathrm{C} \text { age } \\
(\mathrm{yr} \mathrm{BP})\end{array}$ & $\pm 1 \sigma$ & $\begin{array}{c}\text { Averaged } \\
{ }^{14} \mathrm{C} \text { age } \\
(\mathrm{yr} \mathrm{BP})\end{array}$ & $\pm 1 \sigma$ \\
\hline 1 & 35007 & 194 & 0.56 & 0.9 & 0.9478 & 0.0016 & 430 & 15 & \multirow{3}{*}{430} & \multirow{3}{*}{20} \\
\hline 1 & 35008 & $\mathrm{~N} / \mathrm{A}^{\mathrm{a}}$ & 1.11 & N/A & 0.9498 & 0.0014 & 415 & 15 & & \\
\hline 1 & 36290 & 104 & 0.89 & 0.9 & 0.9448 & 0.0012 & 455 & 15 & & \\
\hline 2 & 39042 & 90.3 & 0.35 & 0.4 & 0.8052 & 0.0023 & 1740 & 25 & \multirow{3}{*}{2000} & \multirow{3}{*}{230} \\
\hline 2 & 45438 & 47 & 0.19 & 0.41 & 0.7743 & 0.0045 & 2055 & 50 & & \\
\hline 2 & 45439 & 15.1 & 0.06 & 0.42 & 0.7611 & 0.0151 & 2190 & 160 & & \\
\hline 3 & 38692 & 96.9 & 0.15 & 0.16 & 0.7896 & 0.0050 & 1900 & 60 & \multirow{2}{*}{2120} & \multirow{2}{*}{300} \\
\hline 3 & 38783 & 10.7 & 0.02 & 0.18 & 0.7483 & 0.0295 & 2330 & 320 & & \\
\hline 4 & 45440 & 16.5 & 0.088 & 0.55 & 0.7095 & 0.0100 & 2760 & 120 & N/A & \\
\hline
\end{tabular}

${ }^{\text {a }}$ Graphite target was produced from a $\mathrm{CO}_{2}$ split of UCIAMS35007; ${ }^{\mathrm{b}}$ average ${ }^{14} \mathrm{C}$ ages have been rounded to the nearest 10.

Piperno and Becker, 1996; McClaran and Umlauf, 2000; Piperno and Stothert, 2003; Piperno, 2006; McMichael et al., 2012). Moreover, most attempts at matching ${ }^{14} \mathrm{C}$ ages of phytoliths with independent chronologies failed (Prior et al., 2005; Rieser et al., 2007; Boaretto, 2009). Researchers believed that the underlying problems were associated with stratigraphic disturbances (Kelly et al., 1991) and/or with phytolith sample extraction methods (Boaretto, 2009; Prior et al., 2005; Rieser et al., 2007). The most successful results reported are from Piperno's work (Piperno and Stothert, 2003), with one phytC ${ }^{14} \mathrm{C}$ value matching with results obtained from charcoal and shells. However, none of these phytolith ${ }^{14} \mathrm{C}$ studies have measured blanks to evaluate the background introduced by the chemical extractions, or have used phytoliths of known ages to directly evaluate the accuracy of the results obtained. Published results on putative "modern" phytolith assemblages are usually limited to $\delta^{13} \mathrm{C}$ measurements (Smith and White, 2004; Piperno, 2006; Carter, 2009). In most cases, the associated chronology was obtained by independent dating techniques, or by ${ }^{14} \mathrm{C}$-AMS measurements on other organic materials, or by assuming that $\mathrm{C}$ occluded in phytoliths from living plants must be from photosynthesis (Carter, 2009; Elbaum et al., 2009; Kelly et al., 1991; Piperno, 2006; Raven et al., 1999; Smith and Anderson, 2001; Wilding, 1967) and must therefore be modern. The only ${ }^{14} \mathrm{C}$ dating of recent (post-bomb) phytoliths that we could find was a measurement published by Piperno and Becker (1996) on a phytolith assemblage from a soil depth of $0-20 \mathrm{~cm}$ from a tropical forest floor. Previously extracted phytolith material was combusted and graphitized at the University of California, Riverside and measured at CAMS/Livermore, without procedural blanks for the phytolith extraction procedure. As far as we are aware, this is the only "modern" phytolith ${ }^{14} \mathrm{C}$ result published, and the sole evidence that carbon associated with phytolith assemblages reflects present-day ${ }^{14} \mathrm{CO}_{2}$ atmospheric conditions. In a recent work, McMichael et al. (2012) measured phytoliths and charcoal fragments from soil profiles by ${ }^{14} \mathrm{C}$-AMS to study spatial and temporal scales of pre-Columbian anthropogenic disturbances. The topsoil phytolith assemblages yielded ages ranging from 1.7 to $2.9 \mathrm{kyr} \mathrm{BP}$. The long residence time of phytoliths in soils may explain these old ages. Nevertheless, the shortage of "modern" phytolith ${ }^{14} \mathrm{C}$ results in the literature remains disconcerting.

Sullivan and colleagues (Sullivan et al., 2008) recently reported ${ }^{14} \mathrm{C}$ results for phytC extracted from mature and recently senesced bamboo leaves as 3.5 and $1.9 \mathrm{kyr} \mathrm{BP}$, respectively, based on measurements at the Australian Nuclear Science and Technology Organization (ANSTO) AMS facility. The authors attributed the "old" ${ }^{14} \mathrm{C}$ ages to a massive fractionation of the ${ }^{14} \mathrm{C}$ in the phytC, though the associated $\delta^{13} \mathrm{C}$ values were unaffected $(-27.5 \%$ o for mature and $-30 \%$ o for recently senesced leaves). Thus, although mass-dependent fractionation determined from the measurement of $\delta^{13} \mathrm{C}$ of the sample must be taken into account in calculating ${ }^{14} \mathrm{C}$ results, the age offsets observed by Sullivan et al. (2008) and 
Table 2. Radiocarbon results shown are from harvested grasses phytolith concentrates, bulk grass tissue and atmospheric $\mathrm{CO}_{2}$ extracted from air cans collected in the rural areas from which the grasses were collected. Phytolith extractions were performed by two laboratories (CEREGE, France and UW, USA), following the Kelly et al. (1991) phytolith extraction protocol for plant tissue, as described in Santos et al. (2010a). Radiocarbon results and associated uncertainties were calculated using procedural blanks from $\mathrm{SiO}_{2}$ (to mimic opal phytolith) subjected to the same chemical phytolith extraction as that used for plants. Table adapted from Santos et al. (2010a).

\begin{tabular}{|c|c|c|c|c|c|c|c|c|c|c|}
\hline Sampling site & Sample ID & Material dated & UCIAMS\# & $\begin{array}{l}\text { Sample } \\
(\mathrm{mg})\end{array}$ & $\begin{array}{l}\text { Graphite } \\
(\mathrm{mgC})\end{array}$ & $\begin{array}{l}\text { Sample } \\
\text { Yield (\%) }\end{array}$ & $\begin{array}{l}{ }^{14} \mathrm{C} \text { age } \\
(\mathrm{yr} \mathrm{BP})\end{array}$ & $\pm 1 \sigma$ & $\begin{array}{l}\Delta^{14} \mathrm{C} \\
(\% \circ)\end{array}$ & $\pm 1 \sigma$ \\
\hline \multirow{3}{*}{$\begin{array}{l}\text { Crop field near } \\
\text { Calas; at } 5 \mathrm{~km} \text { from } \\
\text { CEREGE/France }\end{array}$} & \multirow{3}{*}{$\begin{array}{l}\text { Grass } 1 \text {, } \\
\text { harvested in } \\
2007\end{array}$} & \multirow{3}{*}{$\begin{array}{l}\text { Extracted } \\
\text { phytolith by } \\
\text { CEREGE }\end{array}$} & 45448 & 119 & 0.21 & 0.19 & 2005 & 45 & - & - \\
\hline & & & 45449 & 54.8 & 0.052 & 0.1 & 2310 & 200 & - & - \\
\hline & & & 45450 & 18.5 & 0.019 & 0.11 & 2520 & 690 & - & - \\
\hline \multirow{3}{*}{$\begin{array}{l}\text { Nature preserve in } \\
\text { Madison, Wisconsin, } \\
\text { USA }\end{array}$} & \multirow{3}{*}{$\begin{array}{l}\text { Biocore Prairie, } \\
\text { harvested in } \\
2008\end{array}$} & $\begin{array}{l}\text { Extracted phytolith } \\
\text { by UW/USA }\end{array}$ & 49703 & 80 & 0.047 & 0.13 & 8040 & 560 & - & - \\
\hline & & Plant tissue & $48633 ; 34$ & $\sim 4.4$ each & 0.9 & 48.7 & Modern & - & $\begin{array}{l}47.5 \\
(n=2)\end{array}$ & 4.9 \\
\hline & & $\begin{array}{l}\mathrm{CO}_{2} \text { extracted } \\
\text { from air }\end{array}$ & 49543 & $\mathrm{~N} / \mathrm{A}$ & 0.33 & N/A & Modern & - & 44.4 & 2.4 \\
\hline \multirow{3}{*}{$\begin{array}{l}\text { Rural area in } \\
\text { Minnesota, USA }\end{array}$} & \multirow{3}{*}{$\begin{array}{l}\text { MN, harvested } \\
\text { in } 2008\end{array}$} & $\begin{array}{l}\text { Extracted phytolith } \\
\text { by UW/USA }\end{array}$ & 49704 & 190 & 0.11 & 0.09 & 5000 & 140 & - & - \\
\hline & & Plant tissue & 49707; 08 & $\sim 2.0$ each & 0.87 & 53.2 & Modern & - & $\begin{array}{l}53.1 \\
(n=2)\end{array}$ & 1.1 \\
\hline & & $\begin{array}{l}\mathrm{CO}_{2} \text { extracted } \\
\text { from air }\end{array}$ & 49544 & N/A & 0.33 & N/A & Modern & - & 42.4 & 2.1 \\
\hline
\end{tabular}

Santos et al. (2010a) cannot be attributed to isotopic fractionation for the following reasons: (a) the age offsets in both studies are far too large to be caused by any known fractionation mechanism; (b) the IRMS $\delta^{13} \mathrm{C}$ results reported by Sullivan et al. (2008) showed no unusual effects; and (c) ${ }^{14} \mathrm{C}$ results from UCI (Santos et al., 2007) are corrected using $\delta^{13} \mathrm{C}$ values from AMS spectrometer itself, and are therefore insensitive to any "machine" isotopic shifts as well as the natural and sample preparation fractionation combined.

In $\delta^{13} \mathrm{C}$ studies, Smith and White (2004) and Piperno (2006) showed that phytolith $\delta^{13} \mathrm{C}$ values were 4 to $9 \%$ lighter than $\delta^{13} \mathrm{C}$ values obtained for the plant tissues and that the amplitude of the bias was different for $\mathrm{C} 3$ and C4 plants. Smith and Anderson (2001) suggested that the trend might be associated with a tendency of phytoliths to trap lipids (normally depleted in ${ }^{13} \mathrm{C}$ ), but since their extraction and analysis methods could only measure lipids, the overall composition of the phytC was not addressed. Recently, Webb and Longstaffe (2010) questioned the use of $\delta^{13} \mathrm{C}$ measurements of soil-phytolith assemblages to identify shifts in grassland $\mathrm{C} 3 / \mathrm{C} 4$ ratios. They found lower $\delta^{13} \mathrm{C}$ values of phytC extracted from a $\mathrm{C} 4$ grass Calamovilfa longifolia than previously reported, which overlapped with the range of phytC $\delta^{13} \mathrm{C}$ reported for $\mathrm{C} 3$ plants. They suggested that $\delta^{13} \mathrm{C}$ of atmospheric $\mathrm{CO}_{2}$ is not necessarily reflected in $\delta^{13} \mathrm{C}$ of phytC and that phytC may be enriched in several ${ }^{13} \mathrm{C}$-depleted organic compounds, such as fatty alcohols, alkanes, amines, lignins, sugars and lipids, leading to an average $\delta^{13} \mathrm{C}$ value different from the bulk plant $\delta^{13} \mathrm{C}$ value.

\section{Plant carbon sources (photosynthesis versus root uptake)}

Almost all of the $\mathrm{C}$ within plant tissue ( $>97 \%$ ) is thought to be from photosynthesized atmospheric $\mathrm{CO}_{2}$ (Ford et al., 2007) with the rate of $C$ assimilation being regulated by factors such as drought and water stresses, irradiance level, nutrient availability, soil compaction and plant maturation (Chaves et al., 2002; Tubeileh et al., 2003). In addition plants can also assimilate older $\mathrm{C}$ through photosynthesis, if ${ }^{14} \mathrm{C}$ depleted $\mathrm{CO}_{2}$ emission sources are present. For example, Hsueh et al. (2007) compared ${ }^{14} \mathrm{C} / \mathrm{C}$ ratios $\left(\Delta^{14} \mathrm{C}\right)$ of $\mathrm{CO}_{2}$ in clean air from Pt. Barrow, Alaska with ${ }^{14} \mathrm{C}$ in leaves of corn plants sampled throughout the United States in 2004. Corn plants close to large urban areas showed lower $\Delta^{14} \mathrm{C}$ values and consequently older apparent ${ }^{14} \mathrm{C}$ ages, though only by a few decades. Plants can also make use of recycled $\mathrm{CO}_{2}$ respired from soils, which is produced by microbial decay of detrital C (e.g., dead leaves, roots, branches and wood). However, although the ${ }^{14} \mathrm{C}$ of the soil $\mathrm{CO}_{2}$ may be variable, soil $\mathrm{CO}_{2}$ fluxes are typically dominated by fast-turnover (or young) components (Trumbore, 2009); moreover, this effect is usually small even for plants growing under heavy canopy vegetation. Furthermore, these mechanisms affect all photosynthate and cannot explain anomalously old phytC results.

On the other hand, it is now recognized that plants can acquire nitrogen and $\mathrm{C}$ from soil organic matter (SOM), via mutualistic mycorrhizal fungi that colonize plant roots (Nasholm et al., 1998, 2009; Talbot and Treseder, 2010; Talbot et al., 2008). This contradicts the early assumption that 
plants acquire $\mathrm{N}$ in inorganic forms, as nitrate $\left(\mathrm{NO}^{3-}\right)$ and ammonium $\left(\mathrm{NH}^{4+}\right)$ ions. Mycorrhizal fungi acquire nutrients from soil and transfer a portion to their host plants (Smith and Read, 1997) and have been shown to take up intact amino acids from soil (which implies direct uptake of organic $\mathrm{C}$ as well) while in association with a host plant (Abuzinadah and Read, 1986; Bajwa and Read, 1986; Finlay et al., 1992; Hawkins et al., 2000; Taylor et al., 2004; Whiteside et al., 2009). Moreover, mycorrhizal plants from boreal forests (Nasholm et al., 1998; Nordin et al., 2001), temperate grasslands (Bardgett et al., 2003; Weigelt et al., 2003), and wetlands (Henry and Jefferies, 2003) accumulate both ${ }^{13} \mathrm{C}$ and ${ }^{15} \mathrm{~N}$ from isotopically labeled amino acids applied directly to field soil.

Plant species that do not form mycorrhizal symbioses ( $\sim 10 \%$ of land plant families) are also able to take up organic N directly from soil. Paungfoo-Lonhienne et al. (2008) showed that those species can use protein as an $\mathrm{N}$ source for growth without assistance from other organisms and identified two mechanisms by which roots access protein. Roots can exude proteolytic enzymes that digest protein at the root surface and possibly also in the apoplast of the root cortex, and they can also perform endocytosis, a process by which root cells absorb molecules by engulfing them. These findings suggest that the range of $\mathrm{N}$ sources for plants is bigger than initially thought, and that plants might be actively involved in the turnover of SOM. Clearly if plants are taking up organic $\mathrm{N}$, by definition they are also taking up organic $\mathrm{C}$.

Several studies on inorganic $\mathrm{C}$ uptake by terrestrial plants have been carried out since the early 1950s (Vuorinen et al., 1992). Although researchers seem to agree that soildissolved inorganic carbon (DIC) accounted for $<3 \%$ of total leaf-fixed $\mathrm{CO}_{2}$ (Ford et al., 2007; Ubierna et al., 2009), its distribution among above- and below-ground tissue pools can be asymmetrical (for example, $65 \%$ of labeled ${ }^{13} \mathrm{C}$ was found in the Pinus stem against $35 \%$ in its needles; Ford et al., 2007). A recent triple labeling experiment $\left({ }^{15} \mathrm{~N}+{ }^{13} \mathrm{C}+{ }^{14} \mathrm{C}\right)$ demonstrated that maize can take up tracer-C in inorganic form (as $\mathrm{Na}_{2}{ }^{13} \mathrm{CO}_{3}$ and $\mathrm{Na}_{2}{ }^{14} \mathrm{CO}_{3}$ solutions) as well as glycine, and that $5-10 \%$ of all ${ }^{14} \mathrm{C}$ added was recovered from the shoot and root tissue after $24 \mathrm{~h}$ of labeling (Rasmussen et al., 2009).

\section{Organic residues in phytoliths concentrates from harvested grasses}

Multiple phytolith chemical extraction protocols have been developed (Twiss et al., 1969; Carbone, 1977; Geis, 1973; Madella, 1997; Madella et al., 1998), but many of these use organic solvents and should not be used for C isotopic studies. Phytoliths sorb solvents (Santos et al., 2010a) as well as $\mathrm{CO}_{2}$ from air, due to their very large surface area and the strong absorptive properties of clean silica (Hatté et al., 2008; Boaretto, 2009; Santos et al., 2010a). Trapped $\mathrm{CO}_{2}$ can be removed by baking the phytolith extracts at $160^{\circ} \mathrm{C}$ immediately before combustion, but solvent residues are resistant and can bias the ${ }^{14} \mathrm{C}$ results (Santos et al., 2010a). For C isotopic analyses, phytolith extraction protocols mainly use strong acids, such as $\mathrm{HNO}_{3}, \mathrm{H}_{2} \mathrm{SO}_{4}$ and $\mathrm{HClO}_{4}$ for oxidizing the OM (Alexandre et al., 1997; Crespin et al., 2008; Kelly et al., 1991; Prior et al., 2005; Santos et al., 2010a; Smith and White, 2004). Those protocols are very harsh, but $100 \%$ pure phytolith samples are difficult to extract due to the presence of ligneous or waxy components resistant to oxidation, especially (though not exclusively) in harvested plants.

We used scanning electron microscopy (SEM) to further investigate the phytoliths from the ${ }^{14} \mathrm{C}$-dated harvested grasses shown in Table 2, and to evaluate the efficiency of the chemical extractions performed at CEREGE and UWMadison. Leftover phytoliths from vial walls were coated with gold and palladium and scanned with a SEM (Philips XL30). An EDS system (energy-dispersive X-ray spectroscopy, Oxford Instruments) was used to analyze the phytolith material for $\mathrm{Si}$ and $\mathrm{C}$ to obtain semi-quantitative $\mathrm{C}: \mathrm{Si}$ peaks area ratios. Attempts were done to measure $\mathrm{Ca}$ occurrence to detect possible $\mathrm{CaCO}_{3}$ and $\mathrm{CaO}_{\mathrm{x}}$ contaminants from aeolian input, though the possibility that those could survive the phytC preparation seemed remote. SEM pictures and EDS analyses (Fig. 2) are presented for Grass 1 and $\mathrm{MN}$ phytolith concentrates previously analyzed for ${ }^{14} \mathrm{C}$ (Table 2). Unfortunately, the third dated sample shown in Table 2 (Biocore) did not yield enough residual material for a detailed evaluation. Characteristic phytolith types, as well as cuticle-like morphologies that dominate both samples, are made of amorphous silica (Fig. 2a and b). However, organic residues characterized by high $\mathrm{C}: \mathrm{Si}$ peak area ratios were found in both samples (Fig. 2c and d), these organic particles being far more abundant in the MN concentrate. The samples were free of $\mathrm{Ca}$. The SEM-EDS investigation confirmed that Grass 1 and MN samples still contained some organic residues. This calls into question the efficiency of the extraction protocols adapted from Kelly et al. (1991), and possibly the Mulholland and Prior (1993), Smith and White (2004), Prior et al. (2005) or Piperno (2006) protocols, which all involve similar steps. Dry ashing and microwave digestion were also used for phytolith extraction but did not seem to succeed in removing all organic compounds from phytolith concentrates, as evidenced from microscopic pictures (Parr et al., 2001; Parr, 2002). As organic remains may bias isotopic signatures of phytC (both ${ }^{14} \mathrm{C}$ and $\delta^{13} \mathrm{C}$ ), a careful reevaluation of published extraction protocols is needed.

\section{Discussion}

Based on the information from the literature and our experimental results discussed above, several hypotheses for explaining the anomalously old ${ }^{14} \mathrm{C}$ ages for phytC can be rejected. Wilding (1967) suggested that the rigorous chemical 


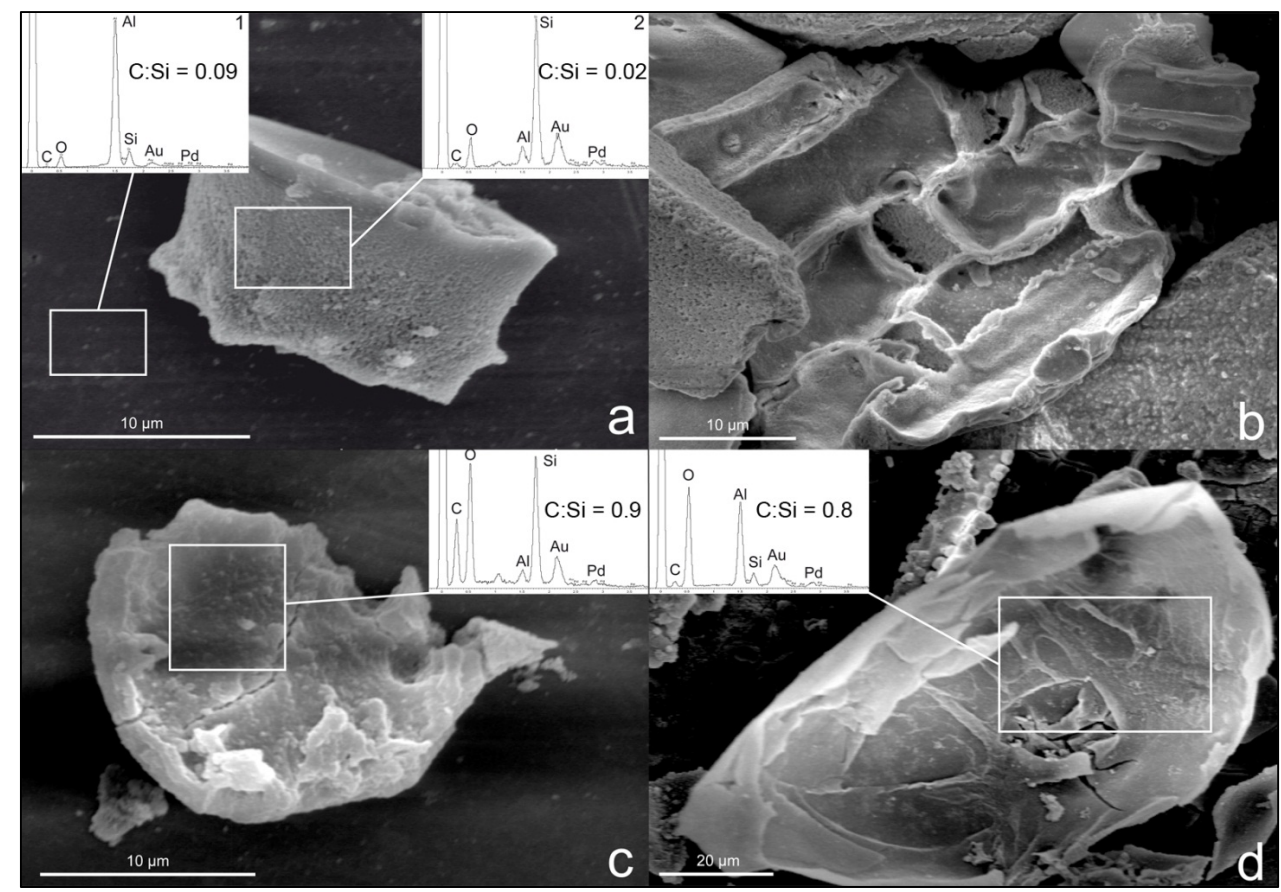

Fig. 2. Phytolith concentrates from Grass 1 and MN samples extracted at CEREGE and at the SSAL laboratory at the University of WisconsinMadison, respectively (Santos et al., 2010a). Note that phytoliths obtained from these samples yielded apparent ${ }^{14} \mathrm{C}$-AMS ages of $2005 \pm 45$ (UCIAMS45448), $2310 \pm 200$ (UCIAMS 45449), $2520 \pm 690$ (UCIAMS 45450) and $5000 \pm 140$ (UCIAMS49704) yr BP, whereas bulk biomass and atmospheric $\mathrm{CO}_{2}$ from the growth sites gave contemporary ${ }^{14} \mathrm{C}$ values (Table 2). SEM images and EDS spectra reveal the following: characteristic phytolith types such as the rondel type (a) and cuticle-like morphologies (b), here from Grass 1, are present in the concentrates. These show semi-quantitative C:Si peak area ratios (a-2) lower than or close to the ratio measured on the Al sample holder (a-1). Other (non-phytolith) organic particles are however present in both the Grass 1 (c) and MN (d) concentrates, and these show much higher C:Si ratios.

oxidation applied in phytolith extractions may have preferentially digested younger opal structures. In our case, this hypothesis does not apply, because our ${ }^{14} \mathrm{C}$ results include data from phytoliths extracted from recently harvested grasses. We believe that our very comprehensive blank assessments for phytolith ${ }^{14} \mathrm{C}$ measurements (Santos et al., 2010a) effectively rule out chemical contamination during the extractions as a likely cause. Moreover, large and small AMS targets produced from pools of phytoliths showed consistent old ${ }^{14} \mathrm{C}$ ages (Tables 1 and 2), indicating that the results are not an artifact of errors in small-sample background corrections. No $\delta^{13} \mathrm{C}$ shifts even remotely comparable with the very large observed ${ }^{14} \mathrm{C}$ depletions have been found, and isotopic fractionation is automatically compensated for in ${ }^{14} \mathrm{C}$ age calculations. SEM-EDS analyses showed no sign of any residues from aeolian dust deposited on the living grasses, as expected given the harsh chemical extractions applied. Furthermore, based on our results shown in Table 2, this hypothesis would imply that approximately $30 \%, 50 \%$ and $70 \%$ of the total $\mathrm{C}$ measured from the phytoliths extracted from the samples Grass 1, MN and Biocore respectively must be ${ }^{14} \mathrm{C}$-dead material from dust input, which is also unlikely. Plausible uptake of old C via photosynthesis is far too small an effect to explain the old phytolith ages and provides no mechanism for selectively biasing the phytC.

Although rates of decomposition of OM vary widely among ecosystems, studies have shown that the SOM ${ }^{14} \mathrm{C}$ spectrum yields mean residence times ranging from a few years or decades (labile pool) to hundreds to thousands of years (recalcitrant pool) (McLauchlan and Hobbie, 2004; Trumbore, 2000; Trumbore and Czimczik, 2008). The labile SOM pool normally serves as a source of readily available nutrients, but recent studies showed that some of the old C is not as stable as initially thought (Baisden and Parfitt, 2007) and can also be accessed and broken down by microorganisms (Fontaine et al., 2007; Xiang et al., 2008; Schimel et al., 2011). As outlined above, plants can access SOM or dissolved inorganic carbon via several different mechanisms (Nasholm et al., 1998, 2009; Paungfoo-Lonhienne et al., 2008; Rasmussen et al., 2009; Talbot et al., 2008; Ubierna et al., 2009; Talbot and Treseder, 2010), and there is at least some evidence that this material is unevenly allocated within the plant tissues (Ford et al., 2007).

In order to account for the apparent ${ }^{14} \mathrm{C}$ ages of several thousand years measured on harvested grass phytolith concentrates (Santos et al., 2010a), a very high fraction of the 


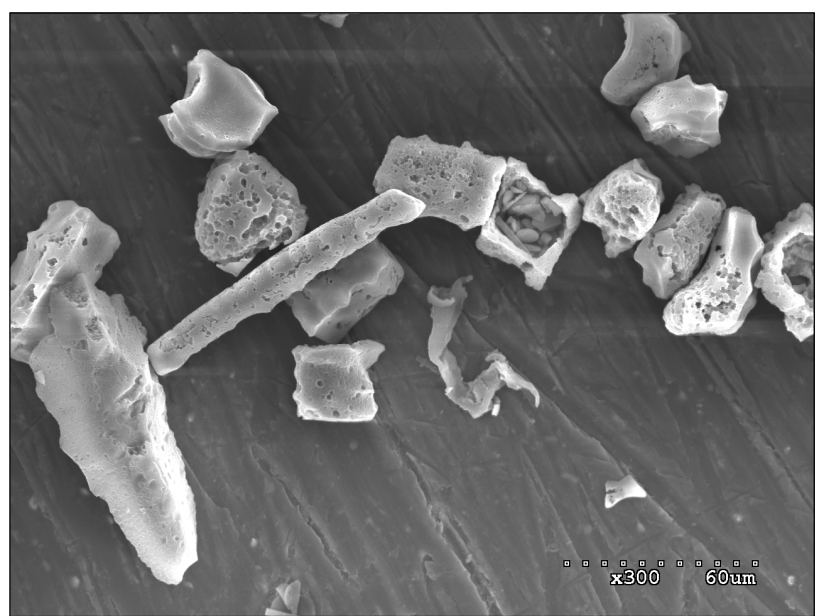

Fig. 3. Phytolith concentrate extracted at CEREGE from the Mascareignite level $(10-20 \mathrm{~cm})$ of volcanoclastic soils from La Reunion, France (Crespin et al., 2008). The SEM image is used here to show typical rough phytolith surfaces.

extracted $\mathrm{C}$ would have to be derived from a refractory SOM component within the very small percentage of the plant $\mathrm{C}$ that originated from root uptake (Paungfoo-Lonhienne et al., 2008; Talbot et al., 2008; Rasmussen et al., 2009; Ubierna et al., 2009; Whiteside et al., 2009). Such a small amount of SOM-derived $\mathrm{C}$ would not shift ${ }^{14} \mathrm{C}$ ages of bulk plant material from its contemporary ${ }^{14} \mathrm{C}$ signals (e.g., modern or post-bomb values). Once old C derived from SOM is incorporated into plant tissue, extractions that do not produce pure phytolith products may leave some of this material in the concentrates. The presence of organic tissue aggregates in the Grass 1 and MN phytolith concentrates (Fig. 2c and d) supports the hypothesis of recalcitrant SOM C biasing the ${ }^{14} \mathrm{C}$ results. Indeed, any SOM C residues might become adsorbed on porous opal surfaces during chemical processing (Fig. 2) or in vivo, which could protect them from further chemical oxidation. Note that the phytC results mentioned above are not due to post-depositional occlusion of SOM, as the material extracted is from living grasses. Nevertheless, post-depositional weathering of phytoliths and increases in surface porosity (Fig. 3) due to environmental conditions have been studied previously (Oleschko et al., 2004), and may partly explain how the ${ }^{14} \mathrm{C}$ age of phytolith concentrates extracted from a top-colluvial soil got older by more than $1.5 \mathrm{ka} \mathrm{yr}$ (Table 1), after some repurification steps (Fig. 1).

McClaran and Umlauf (2000) reported ${ }^{14} \mathrm{C}$ results of total SOM and grass phytoliths extracted from the same soil layers, with phytC much older. These data are consistent with our hypothesis, because their SOM ages are from the total carbon pool (e.g., from a mixture of labile and refractory carbon), whereas we argue that phytC is derived from the refractory (old) component.
Another possibility is that all or most of the $\mathrm{C}$ occluded in phytolith is actually this "recalcitrant" SOM. Previous works have suggested that organic compounds are involved in the actual mineralization process of plant $\mathrm{Si}$ (Kelly et al., 1991; Perry and Lu, 1992; Inanaga et al., 1995; Inanaga and Okasaka, 1995; Harrison, 1996; Elbaum et al., 2009; Bauer et al., 2011). However, none of these studies prove or indicate that these compounds were solely synthesized in the plant. Note that the amount of $\mathrm{SiO}_{2}$ uptake by plants is relatively small (concentrations ranging from 0.1 to $10 \%$ by dry weight; Currie and Perry, 2007) and phytC occluded within phytoliths is $<2 \%$, so that the amounts of phytC involved are very small. If the old ${ }^{14} \mathrm{C}$ ages for phytC are primarily due to old $\mathrm{C}$ within, rather than on the phytoliths, it is even possible that these same SOM C compounds may be directly participating in the Si nucleation process, although direct evidence for this is lacking.

\section{Conclusions}

The review presented here suggests that old $\mathrm{C}$ can be brought from the soil to the plant by root uptake during nutrient recruitment. Although this old component cannot account for more than a few percent of the whole plant $\mathrm{C},{ }^{14} \mathrm{C}$ ages of several thousand years previously obtained from harvested grass phytoliths concentrates (Santos et al., 2010a) suggest that it may become occluded in or attached to the biogenic amorphous silica structure. Very little is known of the location of any old $\mathrm{C}$ within the plant tissues or of the chelation (bonding) of Si to organic compounds in the plant sap and the cells, so it cannot presently be determined whether old $\mathrm{C}$ is directly involved in phytolith formation. Alternatively, since chemical extraction procedures that can remove all plant residues from phytolith concentrates are still lacking, the assumption that old $\mathrm{C}$ may also concentrate in $\mathrm{OM}$ remains attached to phytoliths cannot be excluded. Until such efficient extraction methods are available, the question of whether plants are occluding old $\mathrm{C}$ within phytoliths (as a by-product or biologically-driven) will remain open.

\section{Future directions}

To further investigate the phytC source, we are planning to measure ${ }^{14} \mathrm{C}$ and $\delta^{13} \mathrm{C}$ of extracted phytoliths from grasses that are growing within a $\mathrm{CO}_{2}$-enriched versus a non-enriched environment. Photosynthesized plant material grown under elevated concentrations of ${ }^{14} \mathrm{C}$ dead $\mathrm{CO}_{2}$ should carry distinct $\delta^{13} \mathrm{C}$ and $\Delta^{14} \mathrm{C}$ "tags" derived from the excess $\mathrm{CO}_{2}$ relative to plant material growing in normal atmospheric air. In addition, as an independent verification that carbon from SOM pools is taken up by plants and incorporated into phytoliths, we are also manipulating soil organic compounds using substrate/medium devoid of $\mathrm{C}$ and nutrients with well-characterized carbon isotope signals. Such 
proposed experiments should support or refute the occlusion of soil C in biogenic silica.

Since incomplete sample chemical pre-treatment may only partially remove SOM attached to phytolith surfaces, improved chemical extraction procedures still need to be designed in order to achieve reliable ${ }^{14} \mathrm{C}$ results. We are therefore developing a new and more rigorous phytolith extraction protocol, involving repeated purification steps to produce phytolith concentrates of high purity.

The results of this work will improve our understanding of Si biosynthesis, shed light on the complexity of the plant $\mathrm{C}$ balance (photosynthesis versus root uptake), and reveal the role played by the $\mathrm{C}$ occluded in opal $\mathrm{Si}$. As a spinoff, it will also produce a standardized phytolith extraction procedure reliable for ${ }^{14} \mathrm{C}$ applications.

Acknowledgements. The authors would like to thank Hector Martinez and Shari Bush for their invaluable assistance with literature searches and article retrieval, Claudia Czimczik for her helpful comments on an earlier version of this paper, 3 anonymous reviewers for their valuable suggestions as well as the managing editor, Kirsten Thonicke. This research was supported by the KCCAMS Facility, ECCOREV 2011 (CNRS) and AIR Archéométrie 2011 (CNRS, Aix-Marseille Université).

Edited by: K. Thonicke

\section{References}

Abuzinadah, R. A. and Read, D. J.: The role of proteins in the nitrogen nutrition of ectomycorrhizal plants - I. Utilization of peptides and proteins by ectomycorrhizal fungi, New Phytol., 103, 481-493, 1986.

Alam, A. K. M. M., Xie, S., and Wallis, L. A.: Reconstructing late Holocene palaeoenvironments in Bangladesh: phytolith analysis of archaeological soils from Somapura Mahavihara site in the Paharpur area, Badalgacchi Upazila, Naogaon District, Bangladesh, J. Archaeol. Sci., 36, 504-512, 2009.

Alexandre, A., Meunier, J., Colin, F., and Koud, J.: Plant impact on the biogeochemical cycle of silicon and related weathering processes, Geochim. Cosmochim. Ac., 61, 677-682, 1997.

Alexandre, A., Meunier, J., Mariotti, A., and Soubies, F.: Late Holocene paleoenvironmental record from a latosol at Salitre (Southern Central Brazil): phytolith and carbon isotope evidence, Quaternary Res., 51, 187-194, 1999.

Alexandre, A., Bouvet, M., and Abbadie, L.: The role ofsavannas in the terrestrial $\mathrm{Si}$ cycle: a case-study from Lamto, Ivory Coast, Global Planet. Change, 78, 162-169, doi:10.1016/j.gloplacha.2011.06.007, 2011.

Baisden, W. and Parfitt, R.: Bomb C-14 enrichment indicates decadal C pool in deep soil?, Biogeochemistry, 85, 59-68, 2007.

Bajwa, R. and Read, D.: Utilization of mineral and amino-N sources by the ericoid mycorrhizalendophyte Hymenoscyphusericaeand by mycorrhizal and nonmycorrhizal seedlings of Vaccinium, T. Brit. Mycol. Soc., 87, 269-277, 1986.
Bardgett, R. D., Streeter, T. C., and Bol, R.: Soil microbes compete effectively with plants for organic-nitrogen inputs to temperate grasslands, Ecology, 84, 1277-1287, 2003.

Bauer, P., Elbaum, R., and Weiss, I. M.: Calcium and silicon mineralization in land plants: transport, structure and function, Plant Sci., 180, 746-756, 2011.

Blecker, S. W., McCulley, R. L., Chadwick, O. A., and Kelly, E. F.: Biologic cycling of silica across a grassland bioclimosequence, Global Biogeochem. Cy., 20, GB3023, doi:10.1029/2006GB002690, 2006.

Boaretto, E.: Dating materials in good archaeological contexts: the next challenge for radiocarbon analysis, Radiocarbon, 51, 275281, 2009.

Bremond, L., Alexandre, A., Hely, C., and Guiot, J.: A phytolith index as a proxy of tree cover density in tropical areas: calibration with leaf area index along a forest-savanna transect in Southeastern Cameroon, Global Planet. Change, 45, 277-293, 2005.

Bremond, L., Alexandre, A., Peyron, O., and Guiot, J.: Definition of grassland biomes from phytoliths in West Africa, J. Biogeogr., 35, 2039-2048, 2008a.

Bremond, L., Alexandre, A., Wooller, M. J., Hely, C., Williamson, D., Schafer, P. A., Majule, A., and Guiot, J.: Phytolith indices as proxies of grass subfamilies on East African tropical mountains, Global Planet. Change, 61, 209-224, 2008b.

Carbone, V. A.: Phytoliths as paleoecological indicators, Ann. NY Acad. Sci., 288, 194-205, 1977.

Carter, J. A.: Atmospheric carbon isotope signatures in phytolithoccluded carbon, Quaternary Int., 193, 20-29, 2009.

Chaves, M., Pereira, J., Maroco, J., Rodrigues, M., Ricardo, C., Osorio, M., Carvalho, I., Faria, T., and Pinheiro, C.: How plants cope with water stress in the field: photosynthesis and growth, Ann. Bot.-London, 89, 907-916, 2002.

Cornelis, J.-T., Delvaux, B., Georg, R. B., Lucas, Y., Ranger, J., and Opfergelt, S.: Tracing the origin of dissolved silicon transferred from various soil-plant systems towards rivers: a review, Biogeosciences, 8, 89-112, doi:10.5194/bg-8-89-2011, 2011.

Crespin, J., Alexandre, A., Sylvestre, F., Sonzogni, C., Pailles, C., and Garreta, V.: IR laser extraction technique applied to oxygen isotope analysis of small biogenic silica samples, Anal. Chem., 80, 2372-2378, 2008.

Currie, H. A. and Perry, C. C.: Silica in plants: biological, biochemical and chemical studies, Ann. Bot.-London, 100, 1383-1389, 2007.

Elbaum, R., Melamed-Bessudo, C., Tuross, N., Levy, A. A., and Weiner, S.: New methods to isolate organic materials from silicified phytoliths reveal fragmented glycoproteins but no DNA, Quaternary Int., 193, 11-19, 2009.

Epstein, E.: Silicon, Annu. Rev. Plant Phys., 50, 641-664, 1999.

Epstein, E.: Silicon: its manifold roles in plants, Ann. Appl. Biol., 155, 155-160, 2009.

Finlay, R., Frostegard, A., and Sonnerfeldt, A.: Utilization of organic and inorganic nitrogen sources by ectomycorrhizal fungi in pure culture and in symbiosis with Pinuscontorta Dougl Ex Loud, New Phytol., 120, 105-115, 1992.

Fontaine, S., Barot, S., Barre, P., Bdioui, N., Mary, B., and Rumpel, C.: Stability of organic carbon in deep soil layers controlled by fresh carbon supply, Nature, 450, 277-280, 2007.

Ford, C. R., Wurzburger, N., Hendrick, R. L., and Teskey, R. O.: Soil DIC uptake and fixation in Pinus taeda seedlings and its $\mathrm{C}$ contri- 
bution to plant tissues and ectomycorrhizal fungi, Tree Physiol., 27, 375-383, 2007.

Geis, J. W.: Biogenic silica in selected species of deciduous angiosperms, Soil Sci., 116, 113-110, 1973.

Harrison, C.: Evidence for intramolecular macromolecules containing protein from plant silicas, Phytochemistry, 41, 37-42, 1996.

Hatté, C., Hodgins, G., Jull, A., Bishop, B., and Tesson, B.: Marine chronology based on ${ }^{14} \mathrm{C}$ dating on diatoms proteins, Mar. Chem., 109, 143-151, 2008.

Hawkins, H., Johansen, A., and George, E.: Uptake and transport of organic and inorganic nitrogen by arbuscularmycorrhizal fungi, Plant Soil, 226, 275-285, 2000.

Henriet, C., Draye, X., Oppitz, I., Swennen, R., and Delvaux, B.: Effects, distribution and uptake of silicon in banana (Musa spp.) under controlled conditions, Plant Soil, 287, 359-374, 2006.

Henry, H. A. L. and Jefferies, R. L.: Plant amino acid uptake, soluble $\mathrm{N}$ turnover and microbial $\mathrm{N}$ capture in soils of a grazed Arctic salt marsh, J. Ecol., 91, 627-636, 2003.

Hodson, M. J., White, P. J., Mead, A., and Broadley, M. R.: Phylogenetic variation in the silicon composition of plants, Ann. Bot.London, 96, 1027-1046, 2005.

Hsueh, D. Y., Krakauer, N. Y., Randerson, J. T., Xu, X. M., Trumbore, S. E., and Southon, J. R.: Regional patterns of radiocarbon and fossil fuel-derived $\mathrm{CO}_{2}$ in surface air across North America, Geophys. Res. Lett., 34, L02816, doi:10.1029/2006GL027032, 2007.

Inanaga, S. and Okasaka, A.: Calcium and silicon bindingcompounds in cell-walls of rice shoots, Soil Sci. Plant Nutr., 41, 103-110, 1995.

Inanaga, S., Okasaka, A., and Tanaka, S.: Does silicon exist in association with organic compounds in rice plants?, Soil Sci. Plant Nutr., 41, 111-117, 1995.

Jansson, C., Wullschleger, S., Kalluri, U., and Tuskan, G.: Phytosequestration: carbon biosequestration by plants and the prospects of genetic engineering, Bioscience, 60, 685-696, 2011.

Kelly, E., Amundson, R., Marino, B., and Deniro, M.: Stable isotope ratio of carbon in phytoliths as a quantitative method of monitoring vegetation and climate change, Quaternary Res., 35, 222-233, 1991.

Ma, J. F. and Yamaji, N.: Silicon uptake and accumulation in higher plants, Trends Plant Sci., 11, 392-397, 2006.

Ma, J. F., Goto, S., Tamai, K., and Ichii, M.: Role of root hairs and lateral roots in silicon uptake by rice, Plant Physiol., 127, 17731780, 2001

Ma, J. F., Mitani, N., Nagao, S., Konishi, S., Tamai, K., Iwashita, T., and Yano, M.: Characterization of Si uptake system and molecular mapping of Si transporter gene in rice, Plant Physiol., 136, 3284-3289, 2004.

Ma, J. F., Tamai, K., Yamaji, N., Mitani, N., Konishi, S., Katsuhara, M., Ishiguro, M., Murata, Y., and Yano, M.: A silicon transporter in rice, Nature, 440, 688-691, 2006.

Ma, J. F., Yamaji, N., Mitani, N., Tamai, K., Konishi, Fujiwara, T., Katsuhara, M., and Yano, M.: An efflux transporter of silicon in rice, Nature, 448, 209-212, 2007a.

Ma, J. F., Yamaji, N., Tamai, K., and Mitani, N.: Genotypic difference in silicon uptake and expression of silicon transporter genes in rice, Plant Physiol., 145, 919-924, 2007b.

Madella, M.:Phytolith analysis from the Indus Valley site of KotDiji, Sind, Pakistan, in: Archaeological Sciences 1995, Oxbow
Monograph 64, Oxbow Books, edited by: Sinclair, A., Slater, E., Gowlett, J., Oxford, 294-302, 1997.

Madella, M., Powers-Jones, A. H., and Jones, M. K.: A simple method of extraction of opal phytoliths from sediments using a non-toxic heavy liquid, J. Archaeol. Sci., 25, 801-803, 1998.

Marschner, H.: Mineral Nutrition of higher plants, London: Academic Press, 889 pp., 1995.

McClaran, M. P. and Umlauf, M.: Desert grassland dynamics estimated from carbon isotopes in grass phytoliths and soil organic matter, J. Veg. Sci., 11, 71-76, 2000.

McLauchlan, K. and Hobbie, S.: Comparison of labile soil organic matter fractionation techniques, Soil Sci. Soc. Am. J., 68, 16161625, 2004.

McMichael, C. H., Bush, M. B., Piperno, D. R., Silman, M. R., Zimmerman, A. R., and Anderson, C.: Spatial and temporal scales of pre-Columbian disturbance associated with Western Amazonian lakes, Holocene, 22, 131-141, 2012.

Mitani, N., Chiba, Y., Yamaji, N., and Ma, J.: Identification and characterization of maize and barley Lsi-2-like silicon efflux transporters reveals a distinct silicon uptake system from that in rice, Plant Cell, 21, 2133-2142, 2009.

Mulholland, S. C. and Prior, C. A.: AMS Radiocarbon Dating of Phytoliths, in: Current Research in Phytolith Analysis: Applications in Archaeology and Paleoecology, edited by: Pearsall, D. M. and Piperno, D. R., MASCA Research Papers in Science and Archaeology, 10, 21-23, 1993.

Naidoo, P., Mcfarlane, S., Keeping, M., and Caldwell, P.: Deposition of silicon in leaves of sugarcane (Saccharum spp. hybrids) and its effect on the severity of brown rust caused by pucciniamelanocephala, Proceedings of the South African Sugar Technologists Association, 82, 542-546, 2009.

Nasholm, T., Ekblad, A., Nordin, A., Giesler, R., Hogberg, M., and Hogberg, P.: Boreal forest plants take up organic nitrogen, Nature, 392, 914-916, 1998.

Nasholm, T., Kielland, K., and Ganeteg, U.: Uptake of organic nitrogen by plants, New Phytol., 182, 31-48, 2009.

Neumann, K., Fahmy, A., Lespez, L., Ballouche, L., and Huysecom, E.: The early Holocene paleoenvironment of Ounjougou (Mali): phytoliths in a multyproxy context, Palaeogeogr. Palaeocl., 276, 87-106, 2009.

Nordin, A., Hogberg, P., and Nasholm, T.: Soil nitrogen form and plant nitrogen uptake along a boreal forest productivity gradient, Oecologia, 129, 125-132, 2001.

Oleschko, K., Parrot, J. F., Ronquillo, G., Shoba, S., Stoops, G., and Marcelino, V.: Weathering: Toward a fractal quantifying, Math. Geol., 36, 607-628, 2004.

Parr, J. F.: A comparison of heavy liquid floatation and microwave digestion techniques for the extraction of fossil phytoliths from sediments, Rev. Palaeobot. Palyno, 120, 315-336, 2002.

Parr, J. F., Dolic, V., Lancaster, G., and Boyd, W. E.: A microwave digestion method for the extraction of phytoliths from herbarium specimens, Rev. Palaeobot. Palyno, 116, 203-212, 2001.

Paungfoo-Lonhienne, C., Lonhienne, T. G. A., Rentsch, D., Robinson, N., Christie, M., Webb, R. I., Gamage, H. K., Carroll, B. J., Schenk, P. M., and Schmidt, S.: Plants can use protein as a nitrogen source without assistance from other organisms, P. Natl. Acad. Sci. USA, 105, 4524-4529, 2008.

Peleg, Z., Saranga, Y., Fahima, T., Aharoni, A., and Elbaum, R.: Genetic control over silica deposition in wheat awns, Physiol. 
Plantarum, 140, 10-20, 2010.

Perry, C. and Lu, Y.: Preparation of silicas from silicon complexes: role of cellulose in polymerisation and aggregation control, J. Chem. Soc. Faraday T., 88, 2915-2921, 1992.

Piperno, D. R.: Phytoliths: A Comprehensive Guide for Archaeologists and Paleoecologists, AltaMira Press, New York, 2006.

Piperno, D. R. and Becker, P.: Vegetational history of a site in the Central Amazon Basin derived from phytolith and charcoal records from natural soils, Quaternary Res., 45, 202-209, 1996.

Piperno, D. R. and Stothert, K. E.: Phytolith evidence for early holocene cucurbita domestication in Southwest Ecuador, Science, 299, 1054-1057, 2003.

Prasad, V., Stromberg, C. A., Alimohammadian, H., and Sahni, A.: Dinosaur coprolites and the early evolution of grasses and grazers, Science, 310, 1177-1180, 2005.

Prebble, M., Schallenberg, M., Carter, J., and Shulmeister, J.: An analysis of phytolith assemblages for the quantitative reconstruction of late quaternary environments of the Lower Taieri Plain, Otago, South Island, New Zealand, I. Modern assemblages and transfer functions, J. Paleolimnol., 27, 393-413, 2002.

Prior, C., Carter, J., and Rieser, U.: Are phytolith radiocarbon dates reliable?, Abstract P1592 presented at the 10th International Conference on Accelerator Mass Spectrometry, Berkeley, USA, 5-10 September, 2005.

Prychid, C. J., Rudall, P. J., and Gregory, M.: Systematics and biology of silica bodies in monocotyledons, Bot. Rev., 69, 377-440, 2003.

Ranganathan, S., Suvarchala, V., Rajesh, Y., Srinivasa Prasad, M., Padmakumari, A., and Voleti, S.: Effects of silicon sources on its deposition, chlorophyll content, and disease and pest resistance in rice, Biol. Plantarum, 50, 713-716, 2006.

Rasmussen, J., Sauheitl, L., Eriksen, J., and Kuzyakov, Y.: Plant uptake of dual-labelled organic $\mathrm{N}$ biased by inorganic $\mathrm{C}$ uptake: results of a triple labeling study, Soil Biol. Biochem., 42, 524527, 2009.

Raven, P., Evert, R., and Eichhorn, S.: Biology of Plants, W. H. Freeman and Company/Worth Publishers, New York, New York, 944 pp., 1999.

Rieser, U., Carter, J., and Prior, C.: Phytoliths: a chronometer for the late Quaternary, Abstract 1076 presented at the XVII INQUA 2007 Conference, Cairns, Australia, July/August, 2007.

Rossouw, L., Stynder, D. D., and Haarhof, P.: Evidence for opal phytolith preservation in the Langebaanweg "E" Quarry Varswater Formation and its potential for palaeohabitat reconstruction, S. Afr. J. Sci., 105, 223-227, 2009.

Santos, G. M., Southon, J. R., Griffin, S., Beaupre, S., and Druffel, E.: Ultra small-mass AMS ${ }^{14} \mathrm{C}$ sample preparation and analysis at the KCCAMS/UCI Facility, Nucl. Instrum. Meth. B, 259, $293-$ 302, 2007.

Santos, G. M., Alexandre, A., Coe, H. H. G., Reyerson, P. E., Southon, J. R., and De Carvalho, C. N.: The Phytolith ${ }^{14} \mathrm{C}$ puzzle: a tale of background determinations and accuracy tests, Radiocarbon, 52, 113-128, 2010a.

Santos, G. M., Southon, J., Drenzek, N., Ziolkowski, L., Druffel, E., Xu, X., Zhang, D., Trumbore, S., Eglinton, T., and Hughen, K.: Blank assessment for ultra-small samples: chemical extraction and separation vs. AMS, Radiocarbon, 52, 1322-1335, $2010 \mathrm{~b}$.

Schimel, J. P., Wetterstedt, J. A. M., Holden, P. A., and Trumbore, S. E.: Drying/rewetting cycles mobilize old $\mathrm{C}$ from deep soils from a California annual grassland, Soil Biol. Biochem., 43, 11011103, 2011.

Smith, F. A. and Anderson, K. B.: Characterization of organic compounds in phytoliths: improving the resolving power of phytolith $\delta^{13} \mathrm{C}$ as a tool for paleoecological reconstruction of $\mathrm{C} 3$ and $\mathrm{C} 4$ grasses, in: Phytoliths: Applications in Earth Sciences and Human History, edited by: Meunier, J. D. and Colin, F., A. A. Balkema Publishers, Rotterdam, Netherlands, 317-327, 2001.

Smith, F. A. and White, J. W. C.: Modern calibration of phytolith carbon isotope signatures for $\mathrm{C} 3 / \mathrm{C} 4$ paleograssland reconstruction, Palaeogeogr. Palaeocl., 207, 277-304, 2004.

Smith, S. E. and Read, D. J.: Mycorrhizal Symbiosis, Academic Press, San Diego, 1997.

Street-Perrott, F. A. and Barker, P. A.: Biogenic silica: a neglected component of the coupled global continental biogeochemical cycles of carbon and silicon, Earth Surf. Proc. Land., 33, 14361457, 2008.

Stromberg, C. and McInerney, F.: The Neogene transition from C3 to $\mathrm{C} 4$ grasslands in North America: assemblage analysis of fossil phytoliths, Paleobiology, 37, 50-71, 2011.

Struyf, E., Smis, A., Van Damme, S., Meire, P., and Conley, D.: The global biogeochemical silicon cycle, Silicon, 1, 207-213, 2009.

Sullivan, L. A. and Parr, J. F.: "Green" geosequestration: secure carbon sequestration via plant silica biomineralisation, Geochim. Cosmochim. Ac., 71, A985-A985, 2007.

Sullivan, L., Parr, J., Smith, A., and Jakobsen, G.: Bomb pulse dating of phytolith-occluded carbon for quantification of carbon sequestration in perennial vegetation, Progress Report no. AINGRA08061, AINSE - Australian Institute of Nuclear Science and Engineering, 2008.

Talbot, J. M. and Treseder, K. K.: Controls over mycorrhizal uptake of organic nitrogen, Pedobiologia, 53, 169-179, 2010.

Talbot, J. M., Allison, S. D., and Treseder, K. K.: Decomposers in disguise: mycorrhizal fungi as regulators of soil $\mathrm{C}$ dynamics in ecosystems under global change, Funct. Ecol., 22, 955-963, 2008.

Tamai, K. and Ma, J.: Reexamination of silicon effects on rice growth and production under field conditions using a low silicon mutant, Plant Soil, 307, 21-27, 2008.

Taylor, A. F. S., Gebauer, G., and Read, D. J.: Uptake of nitrogen and carbon from double-labelled (N-15 and C-13) glycine by mycorrhizal pine seedlings, New Phytol., 164, 383-388, 2004.

Trumbore, S.: Age of soil organic matter and soil respiration: radiocarbon constraints on belowground C dynamics, Ecol. Appl., 10, 399-411, 2000.

Trumbore, S.: Radiocarbon and Soil Carbon Dynamics, Annu. Rev. Earth Pl. Sc., 37, 47-66, 2009.

Trumbore, S. E. and Czimczik, C. I.: Geology. An uncertain future for soil carbon, Science, 321, 1455-1456, 2008.

Tubeileh, A., Groleau-Renaud, V., Plantureux, S., and Guckert, A.: Effect of soil compaction on photosynthesis and carbon partitioning within a maize-soil system, Soil Till. Res., 71, 151-161, 2003.

Twiss, P. C., Suess, E., and Smith, R. M.: Morphological classification of grass phytoliths, Soil Sci. Soc. Am. Pro., 33, 109-115, 1969.

Ubierna, N., Kumar, A., Cernusak, L., Pangle, R., Gagl, P., and Marchall, J.: Storage and transpiration have negligible effects on 
$\delta^{13} \mathrm{C}$ of stem $\mathrm{CO}_{2}$ efflux in large conifer trees, Tree Physiol., 29, 1563-1574, 2009.

Vuorinen, A. H., Vapaavuori, E. M., Raatikainen, O., and Lapinjoki, S. P.: Metabolism of inorganic carbon taken up by roots in salix plants, J. Exp. Bot., 43, 789-795, 1992.

Webb, E. and Longstaffe, F.: Limitations on the climatic and ecological signals provided by the $\delta^{13} \mathrm{C}$ values of phytoliths from C4 North American praire grass, Geochim. Cosmochim. Ac., 74, 3041-3050, 2010.

Weigelt, A., King, R., Bol, R., and Bardgett, R. D.: Inter-specific variability in organic nitrogen uptake of three temperate grassland species, J. Plant Nutr. Soil Sc., 166, 606-611, 2003.
Whiteside, M. D., Treseder, K. K., and Atsatt, P. R.: The brighter side of soils: quantum dots track organic nitrogen through fungi and plants, Ecology, 90, 100-108, 2009.

Wilding, L. P.: Radiocarbon dating of biogenetic opal, Science, 156, 66-67, 1967.

Xiang, S.-R., Doyle, A., Holden, P., and Schimel, J.: Drying and rewetting effects on $\mathrm{C}$ and $\mathrm{N}$ mineralization and microbial activity in surface and subsurface California grassland soils, Soil Biol. Biochem., 40, 2281-2289, 2008. 